\title{
Endorectal Coil
}

National Cancer Institute

\section{Source}

National Cancer Institute. Endorectal Coil. NCI Thesaurus. Code C142180.

A thin wire covered with a latex balloon that is inserted into the rectum to enhance the local magnetic field during MRI of the prostate and surrounding tissues. 